\title{
氢火焰离子化鉴定器和毛細管色譜技术交流会
}

中国科学院于 9 月20-23日在大連召开了氢火 蛒离子化鉴定器和毛細管色譜技术交流会。参加会 議的共有 61 个单位的 127 位代表。会上宣讀和討 論了有关毛細管色譜技术、氞火焰离子化鉴定器及 其应用，以及其他相关的設备設計等 18 篇报告。

中国科学院化学物理研究所研究試制成功的氞 火焰离子化鉴定器毛細管色譄仪引起了到会同志的 很大兴趣。这台仪器全部用国产原材料和电子元件 构建。鉴定器的离子流放大器的噪声很小，漂移的 $10^{-13}$ 安/小时; 灵钼度很高, 可測量的最小物貭量 約为 $3 \times 10^{-11}$ 克/秒 (苯)。仪器上用的玻琌毛細管 色譜柱是用該所設計的机器拉制的，內径有 0.05 、 $0.1 、 0.2 、 0.25$ 毫米等四种，长度可达 250 米。經 用自行設計的流动法涂清固定液后, 在分析复杂的 石油烃組成时,柱效能可达每米 3000 理論塔片或每 米 720 有效理論塔片数以上。利用这台仪器, 可以 微量、高速地分析有机物稹,一般可达 2-3 秒紀录 一个色譜寀, 如用示波仪时, 可以快达每秒 20 个色 譜峯。在应用这种仪器进行研究的另一篇报告里指 出, 采用 82 米长的毛細管色譜柱, 在一个牛小时 內, 可将某一汽油样品, 分离出的 100 个化合物的 色譄峯; 而采用 130 米的杜子时,可将某煤油餢分, 分出 152 个色譜峯。这些結果, 使到会同志感到很 滿意。

其他单位的色譜新技术工作，同样引起了到会 同志的注意和热烈討論。例如化工部上海医落工业 研究院設計試制的一种高溫色譜仪，采用离子化鉴 定器和常用的銅色譜柱相联結，可以在 $250^{\circ} \mathrm{C}$ 下工 作。他們将溫度訊号放大后, 用一可逆电机調整电 热絲的电压，从而达到自动控制溫度的目的，㥀溫 可达 $0.1^{\circ} \mathrm{C}$ 的要求。使用这台仪器分析农获以及其 他沸点較高的有机物稹，都获得良好結果。与他們 的試驗不同，兰州化学物理研究所以銅毛細管色譜
柱与热传导鉴定器相联結进行試驗，在三个二甲苯 异构体的分离試驗中得了一些有兴趣的初步結 果。

会議上对离子化鉴定器色譜的定性、定量問題 进行了报告和討論。用氢火烙离子化鉴定器色譄仪 来分析石油中芳䍿組成、含氧化合物含量、烴类燃烧 产物組成，以及氯丁二烯合成气組成等方面的研究， 說明这种仪器对于石油、化学和医溚工业, 以及化 学科学研究等等方面都具有很大的意义, 应該更加 积极地发展。

交流会上还报告和討論了快速离子流放大器、 色譜自动积分仪、簡易离子化鉴定器和簡易离子流 放大器等設备的构造和綫路設計。采用国产材料制 成的自动积分仪，可以进行三种不同形式的积分（自 动退零式、阶梯式和交替式），使色謭工作者急除 了费时的測量与計算，可以直接讀出每个色譜峷的 面积大小。簡易的离子流放大器，結构簡单、成本 很低，虽然灵敏度較差，但具有很大的現实意义， 对某些工作要求較低的单位来說, 是很适用的。

会議总結时指出，氮火焰离子化鉴定器毛細管 色譜技术是最近四年多来国际上出現的新技术，它 具有分离效能高、分析速度快、消耗試料极少等优 点和鉴定极微量杂稹的特点。推广应用这种 新 技 术，将对我国工、农业和科学研究事业有很好的促 进作用。化学物理研究所試制成功的这种仪器已經 过复制应用，效果很好，应該建議有关部門組織小 批試生产，以滿足許多单位的迫切需要，讲在試制 中进一步改进設計，为正式生产創造条件。会議还 訩为, 各单位进行的工作都是有意义的，应該根据 各自的工作目的、要求以及物稹技术条件来选用仪 器, 按照多标准、多途径的方針, 积极吸收新技术, 不断革新工作，把我国科学事业大步向前推进。

\section{[一斌 $]$}

